\title{
References:
}

1. Helbak A. (2017). Formuvannya pidpryyemlyvosti uchnya yak klyuchovoyi kompetentnosti dlya zhyttya [Forming student entrepreneurship as a key competency for life]. Kropyvnyts'kyy: KZ «KOIPPO imeni Vasylya Sukhomlyns'koho» [in Ukrainian].

2. Dovhan A., \& Mazurkevych I. (2015). Suchasni pidkhody do formuvannya kompetentnosti pidpryyemlyvosti ta initsiatyvnosti uchniv zahalnoosvitnikh navchalnykh zakladiv [Modern approaches to formation of entrepreneurship competence and initiative of secondary schools' students.]. Dyrektor shkoly, litseyu, himnaziyi - School headmaster, lyceum, gymnasium, 6, 49-54 [in Ukrainian].

3. Zakon Ukrayiny «Pro osvitu» № 2145-VIII [The Law of Ukraine «On Education»]. (n.d.). zakon.rada.gov.ua. Retrieved from https://zakon.rada.gov.ua/laws/show/2145-19 [in Ukrainian].

4. Moskalenko V., \& Syla T. (2010). Pidpryyemlyvist yak tvorchist [Entrepreneurship as a creativity]. Aktualni problemy psykholohiyi - Actual problems of psychology, 48 (I). 38-45 [in Ukrainian].

5. Pyskun O., \& Sokol N. (2018). Rozvytok pidpryyemlyvosti ta finansovoyi hramotnosti uchniv starshoyi shkoly v protsesi tekhnolohichnoyi osvity [Development of entrepreneurship and financial literacy of high school students in the process of technological education]. Visnyk. Seriya Pedahohichni nauky - Herald. Series: Pedagogical Sciences, 151 (2). 118-122 [in Ukrainian].

6. Tovkalo M. (2014). Yak tvoryty pidpryyemnytske tlo uroku. Uroky z pidpryyemnytskym tlom [How to create an entrepreneurial background of the lesson. Lessons with an entrepreneurial background]. Varshava: Sova [in Ukrainian].

Pryshchepa S. M. Formation of entrepreneurship as a philosophical-pedagogical component of the spiritual sphere of personality in secondary school pupils

The article determines the relevance of the identified problem in accordance with the current situation and the importance of legislative and regulatory documents. Revealed and analyzed the qualities (responsibility, independence, initiative, hard work, creativity, persistence, organization, honesty) that are included in the concept of "entrepreneurship" as one of the key competences.

The essence of the concept "entrepreneurship" from pedagogical, psychological and philosophical points of view is determined.

The importance of entrepreneurship formation is emphasized not only in the lessons of economics, financial literacy, intellectual property, but also in other subjects of secondary education institution.

The essence, features and tools of each of the stages of entrepreneurial competence formation are briefly explained. We outline the main four steps in which the tasks and actions of all the subjects of the educational process are described in the article. It is worth noting that each of these stages is a continuation of the previous stage and the beginning of the next one, as all stages are a system in the formation of this competence.

Analyzing each of the stages, we have identified the use of mainly active learning methods and replacement of monologue presentation for dialogical forms of learning (brainstorming, system analysis, imitation training and exercises, thematic discussions), which would allow students to find solutions to different problems, be independent in making decisions and be able to defend one's point of view.

The article analyzes the purpose and main objectives of the Ukrainian-Polish School Academy of Entrepreneurship project. This project reveals the peculiarities of entrepreneurial competence formation both in class and outclass time, offering forms of work outside school, such as exhibitions, clubs and others.

Attention is drawn to the fact that the implementation of all these stages can help to shape the creativity, imagination, thinking of students.

Key words: entrepreneurship, entrepreneurial competence, students, teaching methods, secondary education institution, quality of entrepreneurship, project, entrepreneurial activity, problem situation, competence approach.

УДК 378.147: 372.881.111.1

DOI https://doi.org/10.31392/NPU-nc.series5.2020.72-2.31

Прокопчук М. М.

\section{СУЧАСНІ ПІДХОДИ ДО ФОРМУВАННЯ ІНШОМОВНОЇ ПРОФЕСІЙНОЇ КОМПЕТЕНТНОСТІ}

Стаття присвячена дослідженню сучасних тенденцій у галузі вивчення англійської мови за професійним спрямуванням. Зокрема, здійснюється аналіз наукових досліджень, пов'язаних із розробкою ефективної методики формування як окремих субкомпетентностей іншомовної професійної компетентності, так $і$ загальних підходів до навчання англійської мови за професійним спрямуванням за останні три роки; описуються предметно-технологічні, сочіальні і психологічні аспекти навчального проиесу та їх вплив на формування навичок використання іноземної мови для здійснення професійної діяльності.

Основна увага зосереджується на теоретико-методичних засадах (системному, компетентнісному, рефлексивному, особистісно-діяльнісному підходах) формування іншомовної професійної компетентності в немовних вищих навчальних закладах; аналізуються особливості рефлексивного підходу, принции свідомості та розвитку автономї студентів в умовах тотальної технологізації освітянської сфери. 
Розкривається сутність таких понять, як іншомовна професійна компетентність, часткова автономія із внутрішнім самоконтролем та із зовнішнім автоматизованим контролем; напівавтономія; умовно повна автономія.

На основі останніх досліджень, пов'язаних із залученням інформаційних технологій до прочесу формування окремих иільових компетентностей, щзо здійснюеться на засадах концептуальності; результативності; економічності; ергономічності; коригованості та візуалізації, уточнюється інструментарій додаткових можливостей студентів.

Серед основних переваг оволодіння необхідними навичками та уміннями з використанням інформаційних технологій виокремлюються такі, як: 1) гнучкість (здатність навчатися у зручний для студента час); 2) технологічність (використання в навчальному процесі нових досягнень інформачійних технологій); 3) якість, яка не поступається традиційному навчанню, соиіальна рівність (однакові можливості для здобуття вищої освіти незалежно від місия прожсивання, стану здоров'я і соціального статусу); 4) інтернаціональність (можливість здобути освіту в навчальних закладах іноземних держав).

Ключові слова: англійська мова за професійним спрямуванням, професійно-орієнтована комунікативна компетентність, рефлексивний підхід, навчальна автономія, інформаційні технології.

Ратифікувавши Угоду про асоціацію між Україною та Європейським Союзом, наша держава стала на шлях глибинних трансформацій у різних сферах суспільного життя.

3 цього часу адаптація європейських норм та стандартів стала одним з першочергових завдань розвитку державного управління, адже реформування потребують аспекти державного регулювання зовнішньо- та внутрішньо-економічної діяльності, агропромислового сектору, малого та середнього бізнесу, регіонального розвитку тощо [12].

Відповідно до Угоди активізація співпраці між Україною та Європейським Союзом відбувається за декількома напрямами, серед них: політичний, економічний, безпековий, правовий. Її метою є посилення політичного діалогу, зміцнення миру й стабільності в регіоні та світі, інтеграції України до внутрішнього ринку СС, забезпечення верховенства права та поваги до прав і основоположних свобод людини, а також тіснішого співробітництва в інших сферах, які становлять взаємний інтерес.

Питання створення ефективної методики навчання англійської мови за професійним спрямуванням (АМПС), яка відповідає на виклики глобальної проникнення інформаційних технологій (IT)у сферу освітніх послух, були в центрі уваги низки вітчизняних науковців, серед яких особливої уваги заслуговують дослідження О. П. Биконі, Г. А. Дивнич, Т. П. Дружченко, О. В. Жовнич, І. С. Заярна, С. В. Лазаренко та ін.

О. П. Биконя обгрунтувала, розробила та експериментально перевірила теоретико-методичні засади організації самостійної позааудиторної роботи майбутніх економістів 3 ділової англійської мови 3 використанням мультимедійного електронного посібника.

Г. А. Дивнич були розроблені практичні рекомендації щодо удосконалення англомовної компетентності посадових осіб органів державної влади України як чинника функціонування механізмів державного управління в умовах євроінтеграції України.

Т. П. Дружченко обгрунтовала й розробила методику диференційованого навчання англійського усного монологічного мовлення майбутніх юристів.

О. В. Жовнич було з'ясовано сутність і специфіку професійно- орієнтованого спілкування майбутніх журналістів й окреслено лінгводидактичні основи навчання професійно-орієнтованого англомовного писемного спілкування майбутніх журналістів засобами блог-технологій.

I. C. Заярна визначила методичні й лінгвістичні засади дистанційного навчання англійського аргументативного писемного мовлення, розробила етапи навчання, створила підсистему вправ і завдань, а також модель організації процесу навчання, опосередкованого комп’ютером.

С. В. Лазаренко було розроблено методику самостійного оволодіння майбутніми військовими фахівцями з IT англомовною лексико-граматичною компетентністю та навчальними стратегіями у читанні $з$ використанням мобільних додатків.

Дослідження зарубіжних вчених (K. Harding, Alan Maley, P. Strevens, A. Waters та ін.) присвячені, головним чином, переосмисленню загальних положень методики викладання АМПС та розв'язанню питань, пов’язаних із процесами глобального проникнення IT у сферу професійної діяльності суспільства.

Не зважаючи на значну кількість публікацій, присвячених питанню розробки ефективної методики формування як окремих цільових компетентностей, так і загальних питань методики АМПС, залишається відкритим питання пошуку ефективної методики формування іншомовної професійної компетентності (ІПК) в умовах тотального проникнення IT у сферу навчання іноземних мов.

Мета статті - Враховуючи необхідність удосконалення методики навчання «Англійська мова за професійним спрямуванням» для здобувачів другого (магістерського) рівня освіти за спеціальністю 281 «Публічне управління та адміністрування», вважаємо за потрібне здійснити аналіз вітчизняних досліджень та з'ясувати основні підходи до формування ІПК за останні три роки.

В більшості вищезазначених робіт АМПС розглядається як інструмент професійної діяльності, що по-різному використовується фахівцями різних професій.

Відповідно, навчання як модель реальної комунікації звужує лінгвістичний діапазон мови до конкретних потреб студентів різних спеціальностей та передбачає використання автентичних матеріалів для формування всіх складових ІПК, яке визначається як складне інтегроване ціле, яке забезпечує компетентне професійне спілкування мовою спеціальності в умовах міжкультурної комунікації [8]. 
За визначенням Програми з АМПС метою навчання іноземним мовам для професійного спілкування $€$ формування не окремого набору елементів, а інтегрованої системи умінь і знань, необхідних для ситуативного та професійного спілкування [11].

Під час досягнення цієї мети у майбутніх фахівців формується достатній рівень ІПК, яку складають іншомовні знання, мовні, комунікативно-пізнавальні, мовленнєві навички й уміння загально-технічного характеру.

Ці знання, навички й уміння забезпечують підготовку до подальшої самостійної роботи з іншомовним матеріалом відповідно до освітніх запитів і гармонійного поєднання навчального процесу та майбутньої професійної діяльності.

К. Хардінг наголошує, що в процесі формування ІПК у студентів немовних вищих закладів необхідно враховувати специфічні умови професійної діяльності, систему виробничих зав'язків, предметно-технологічний, соціальний і психологічний контексти навчання:

- вивчення АМПС розглядають як інструмент для досягнення професійної мети, що виходить за межі формальної лінгвістичної науки;

- наявний невдалий досвід вивчення мови може негативно впливати на мотиваційний аспект вивчення АМПС;

- вивчення АМПС може здійснюватися після роботи або паралельно із вивченням професійно- орієнтованих дисциплін, що спричиняє психологічну та фізичну втому та небажання навчатись;

- вивчення мови не за власним бажанням, а на вимогу адміністрації;

- наявність в одній групі студентів, які володіють АМПС на різних рівнях, що спонукає викладача здійснювати пошук ефективних стратегій та використання методів диференційованого підходу до навчання;

- навчання в одній групі керівників та їхніх підлеглих;

- навчання в одній групі студентів різних професійних галузей;

- невідповідність рівнів володіння студентами АМПС програмним вимогам [13].

Г. А. Дивнич співвідносить ІПК із такими поняттями як «система», «якість особистості», «готовність і здатність»; містить у собі мовознавчі правила, категорії та одиниці мови, їх функції, закономірності, мовні знання, уміння та навички; різні види компетенцій.

Науковець підкреслює, що ІПК є комплексною якістю особистості, набутої в процесі вивчення іноземної мови, яка складається із лінгвістичних, комунікативних і соціокультурних знань, професійних умінь і особистих ставлень, базується на досвіді та проявляється у загальній здатності й готовності до успішної діяльності в іншомовному середовищі [4, с. 7].

Отже, особливістю формування ПКК у процесі вивчення АМПС на сучасному етапі розвитку методичної науки є зміщення акценту від накопичення студентами необхідних знань, умінь і навичок впродовж конкретного відрізку часу до формування готовності навчатися впродовж життя [7, с. 220].

С. В. Лазаренко, досліджуючи психологічні та дидактико-методичні передумови самостійного оволодіння англомовною лексико-граматичною компетентністю у читанні з використанням мобільних додатків, наголошує, що освіта третього тисячоліття спрямована на автономію у навчанні, самовдосконалення, розвиток людини інноваційного типу мислення, тому застосування рефлексивного підходу в процесі навчання якнайкраще сприятиме здійсненню згаданих вище напрямків сучасної освіти [9, с. 71].

Під навчальною автономією студентів розуміють навчання, що здійснюється за рахунок опосередкованого керування викладачем освітнім процесом з метою самостійного оволодіння студентами IПК [1].

За таких умов, у центрі уваги науковців опиняються концептуальні засади організації самостійної роботи студентів, що є формою позааудиторної навчально-пізнавальної діяльності, яку організовує і контролює студент на основі зовнішнього опосередкованого управління викладачем [2, с. 10].

Теоретико-методичні засади самостійної роботи студентів, які вивчають АМСП, висвітлено в досліджені О. П. Биконі. Серед провідних підходів до формування ІПК під час самостійної діяльності науковець виокремлює: 1) системний, 2) компетентнісний, 3) рефлексивний, 4) особистісно-діяльнісний і 5) ситуаційний.

На основі системного підходу досліджуються способи організації елементів системи в єдине ціле, у взаємодії процесів функціонування системи, її підсистем, елементів самостійного позавудиторного навчання студентів АМСП.

У процесі реалізації компетентнісного підходу передбачається розроблення вимог до рівня володіння студентами складовими ІПК.

Основоположним елементом рефлексивного підходу є рефлексія, яка є необхідною умовою ефективності ІПК у навчанні майбутніх фахівців.

На нашу думку, в умовах змінення темпоральних меж формування ІПК, особливої значущості набуває рефлексивний підхід до вивчення АМПС.

До основних принципів цього підходу О. П. Биконя відносить принципи свідомості (студентом усвідомлюється програма навчання АМПС засобами IT) і розвитку автономії студентів.

Із забезпеченням студентів спеціальними навчальними засобами, які можуть створити умови для формування у майбутніх фахівців умінь визначати власні цілі, ставити перед собою конкретні завдання, обирати шляхи і способи їх реалізації, науковцями визначено три рівні автономії студентів: 
1) часткова автономія з внутрішнім самоконтролем та із зовнішнім автоматизованим контролем (викладач визначає мету, завдання, шляхи їхньої реалізації, контролює процес і результат виконання самостійної роботи);

2) напівавтономія (викладач визначає мету і завдання, надає студентам відносну свободу щодо добору шляхів, у тому числі й із запропонованих, та ходу виконання завдання, контролює його результат);

3) умовно повна автономія (передбачається самостійне визначення студентом рубіжних і кінцевих цілей з урахуванням програмних вимог та індивідуальних потреб; можливість консультування за потреби 3 викладачем; самостійна реалізація поставлених завдань; самоконтроль і самокорекція, оцінювання результатів) $[2 ; 7 ; 9]$.

У більшості робіт науковцями наголошується на необхідності реалізації рівня напівавтономії у процесі самостійного формування ІПК та доцільності реалізації часткової та напівавтономії з внутрішнім самоконтролем у навчанні АМПС.

Однак залишається відкритим питання створення таких методик, які створюють підгрунтя для досягнення рівня умовно повної автономії в умовах, коли необхідність навчатись впродовж всього життя стає невід'ємним атрибутом сьогодення, а формування трансферабельних навичок стає викликом для більшої частини працездатного населення України.

У цьому аспекті цікавими є результати опитування 12000 осіб віком 16 - 70 років із 19 країн міжнародної освітньою компанією Пірсон, проведеною в 2019 році [14].

Відповідно до результатів опитування вісім основних трендів набувають популярності в галузі вищої освіти, а саме:

1) самонавчання як провідна форма отримання освітніх послуг, коли кожна людина отримує можливість самостійно обирати що, коли та як вивчати;

2) навчання стає невід'ємною і постійною частиною життєвого циклу, надаючи можливість кожному за власним бажанням змінювати професію відповідно до особистих потреб;

3) цифрова та віртуальна форми навчання стануть невід’ємною частиною життя у найближчі десять років;

4) навчальні заклади як інституціальні об’єкти поступово втрачають соціальну значущість, оскільки не готують до професійної діяльності у відповідності до вимог цільового користувача освітніх послуг, а навчання є занадто дорогими та не враховує індивідуальні потреби особистості;

5) навички соціальної взаємодії набувають більш вагомої соціальної цінності порівняно 3 навичками автоматизації виробництва [14].

Необхідність пошуку нових підходів до навчання АМПС також пов'язано із глобальним інтернет-проникненням у більшу частину сфери професійної діяльності людства.

Згідно із результатами моніторингу інтернет-проникнення в Україні, яке на замовлення ІнАУ виконала дослідницька компанія Factum Group, у 2019 році відбулось зростання на 6-7 \% інтернет-користувачів, переважна більшість населення України віком до 35 років є інтернет-користувачами [3].

Однією з причин такого зростання науковці вважають «смартфонізацію» населення. На сьогодні 22 \% користувачів виходять в Інтернет винятково за допомогою смартфонів.

Разом 3 тим, наявність програмного забезпечення та засобу користування навчальними програмами, мобільними додатками, веб-сервісами тощо озброює студентів додатковим набором можливостей, які формальна освіта не може забезпечити, а саме:

- самостійним, на власний розсуд створеним розкладом занять із палітри доступних навчальних курсів онлайн;

- навчанням відповідно до домінантного типу інтелекту та власних біоритмів активності;

- повторенням, поверненням у разі необхідності до навчального матеріалу 3 метою його уточнення, закріплення, проміжного контролю;

- вихованням вольових якостей особистості (самодисципліни, самоорганізованості);

- плануванням робочого дня для ефективного використання робочого та вільного часу;

- контролю часового простору та змісту навчання (внутрішня мотивація) та підвищенням ефективності навчального процесу за рахунок можливостей навчальної програми (зовнішня мотивація);

- перехід від ролі пасивного об'єкту навчання до активного учасника та творця власного навчального простору.

Нові форми взаємодії учасників навчального процесу, що створюють підгрунтя для технологізації гуманітарної сфери та модернізації процесу підготовки майбутніх фахівців шляхом цілеспрямованої орієнтації iii на поглиблений розвиток аналітичних умінь студентів, їх стратегічного мислення, уміння синтезувати отриману інформацію для вирішення професійних проблем, працювати в команді та швидко адаптуватися до змін, застосовувати фахові знання на практиці знайшли своє відображення у дослідженнях О. В. Жорнич, I. С. Заярна, А. В. Медведчук та інших.

Для успішного формування IПК із залученням нових технологій навчання, на думку А. В. Медведчук, варто здійснювати на засадах:

1) концептуальності - чіткої, послідовної та методичної розробки цілей навчання; 
2) результативності - теоретико-прогностичного вивчення умов і засобів упровадження педагогічних інновацій, прогнозування результатів навчально-виховної діяльності і високого рівня досягнення результатів;

3) економічності - ефективне формування ІПК забезпечується структуруванням, впорядкуванням, ущільненням інформації, що створює підгрунтя для ефективного сприйняття та засвоєння більшого обсягу навчального матеріалу;

4) ергономічності - організація навчання здійснюється в умовах співробітництва і позитивного емоційного мікроклімату;

5) коригованості - можливість вносити процесуальні зміни в навчальний процес із збереженням основних цілей навчання;

6) візуалізації - комплексне застосування технічних, комп’ютерних засобів навчання та контролю [10, с. 90].

О. В. Жовнич пропонує використати сервіси Веб 2.0, зокрема блог-технології, як зручну платформу не лише для отримання інформації, й для комунікативної взаємодії, аргументуючи свій вибір тим фактом, що інтенсивне впровадження ІКТ полегшує комплексне напрацювання англомовних писемних умінь і навичок спілкування майбутніх журналістів, заохочує вивчення мови як реального засобу комунікації, підвищує рівень креативності студентів і впевненість у власних можливостях; формує вміння самостійного вироблення стратегій розв'язання навчальних і практичних завдань [6, с. 16 - 17].

I. C. Заярна розглядає можливості дистанційного навчання, яке покликане удосконалювати і розвивати традиційні очні та заочні форми, інтегруючи в собі те краще, що накопичено ними із застосуванням в навчанні можливостей ІКТ у процесі формування IКК [8, с. 17].

Серед основних переваг оволодіння необхідними навичками та уміннями 3 використанням дистанційного навчання науковець виокремлює:

1) гнучкість (здатність навчатися у зручний для студента час);

2) технологічність (використання в навчальному процесі нових досягнень інформаційних технологій);

2) якість, яка не поступається традиційному навчанню, соціальна рівність (однакові можливості для здобуття вищої освіти незалежно від місця проживання, стану здоров'я і соціального статусу);

3) інтернаціональність (можливість здобути освіту в навчальних закладах іноземних держав); навчання АМПС засобами дистанційного навчання створює низку переваг у процесі виконання поставлених навчальних задач і оволодіння необхідними навичками та уміннями [8, с. 17].

Висновки. Враховуючи вищезазначене, можемо зробити висновок, що сучасними тенденціями у галузі вивченні АМПС $є$ :

1) зміщення акценту від накопичення студентами необхідних знань, умінь і навичок впродовж конкретного відрізку часу до формування готовності навчатися впродовж життя;

2) використання таких методик формування ІПК, що передбачають досягнення студентами рівня часткової та /або напівавтономії у процесі самостійного формування субкомпетентностей ІПК;

3) актуальність ревізії наявного методичного інструментарію для розробки ефективної методики формування ПКК в АМПС із поглибленим розвитком аналітичних умінь студентів, їхнього стратегічного мислення, умінь синтезувати отриману інформацію для вирішення професійних проблем, працювати в команді та швидко адаптуватися до змін, застосовувати фахові знання на практиці у зв'язку із тотальною технологізацію гуманітарної сфери та модернізацією процесу підготовки майбутніх фахівців у ВНЗ України.

Подальшою перспективою в цьому напрямку є обгрунтування та розробка теоретико-методичних засад методики викладання дисципліни «Англійська мова за професійним спрямуванням» для здобувачів другого (магістерського) рівня освіти за спеціальністю 281 «Публічне управління та адміністрування» у закладах вищої освіти.

\section{Використана література:}

1. Азимов Э. Г., Щукин А. Н. Новый словарь методических терминов и понятий (теория и практика обучения языкам). Москва, 2009. 448 с.

2. Биконя О. П. Теоретико-методичні засади самостійної позааудиторної роботи з англійської мови студентів економічних спеціальностей : автореф. дис. ... док. пед. наук : 13.00.02. Київ, 2017. 48 с.

3. В Україні виросла інтернет-пенетрація. URL https:/inau.ua/news/v-ukrayini-znachno-vyrosla-internet-penetraciya (дата звернення 20.12.2019).

4. Дивнич Г. А. Англомовна компетентність як чинник функціонування механізмів державного управління в умовах євроінтеграції України : автореф. дис. ... канд. держ. упр. наук : 25.00.02. Чернігів, 2018. 20 с.

5. Дружченко Т. П. Методика диференційованого навчання англійського усного монологічного мовлення майбутніх юристів : дис. ... канд. пед. наук : 13.00.02. Київ, 2018. 269 с.

6. Жовнич О. В. Методика навчання професійно орієнтованого англомовного писемного спілкування майбутніх журналістів засобами блог-технологій : дис. ... канд. пед. наук : 13.00.02. Тернопіль, 2018. 303 с.

7. Задорожна І. П. Організація самостійної роботи майбутніх учителів англійської мови з практичної мовної підготовки: монографія. Тернопіль, 2011. 414 с.

8. Заярна I. С. Методика дистанційного навчання англійського аргументативного писемного мовлення майбутніх правознавців : дис. .... канд. пед. наук : 13.00.02. Київ, 2019. 234 с.

9. Лазоренко С. В. Методика самостійного оволодіння англомовною лексико-граматичною компетентністю у читанні майбутніми військовими фахівцями з інформаційно телекомунікаційних технологій : дис. ... канд. пед. наук : 13.00.02. Київ, 2018. 209 с. 
10. Медведчук А. В. Формування англомовної професійно орієнтованої компетентності в діалогічному мовленні у майбутніх менеджерів з адміністративної діяльності : дис. ... канд. пед. наук : 13.00.02. Київ, 2019. 296 с.

11. Програма з англійської мови для професійного спілкування / кол. авт.: Г. Є. Бакаєва [та ін.]. Київ : Ленвіт, 2005.119 с.

12. Угода про асоціацію. URL https://www.kmu.gov.ua/diyalnist/yevropejska-integraciya/ugoda-pro-asociacyu (дата звернення 11.01.2020)

13. Harding Keith. English for Specific Purposes. Oxford: Oxford University Press, 2007. 170 p.

14. E-Learning in High Education. URL https:// https://eua.eu/resources/publications/368:e-learning-in-european-higher-educationinstitutions.html

\section{References:}

1. Azimov, E.G., Schukin, A.N. (2009). Novyiy slovar metodicheskih terminov i ponyatiy (teoriya i praktika obucheniya yazyikam) [New Dictionary of Methodological Terms and Notions (theory and practice of language teaching)]. Saint Petersburg, the Russian Federation: Zlatoust [in Russian].

2. Bykonya, O.P. (2017). Teoretyko-metodychni zasady samostiinoi pozaaudytornoi roboty z anhliiskoi movy studentiv ekonomichnykh spetsialnostei [Theoretical and Methodological Foundations of Economic Speciality Students' Independent Extracurricular Self-Study Work on English]. (Doctor's thesis), Kyiv National Linguistic University Ministry of Education ans Science of Ukraine, Kyiv, Ukraine [in Ukrainian].

3. Ukrainian Internet Association (2019). Internet penetration has grown in Ukraine. Retrieved from https://inau.ua/news/v-ukrayiniznachno-vyrosla-internet-penetraciya.

4. Dyvnych, H.A. (2018). Anhlomovna kompetentnist yak chynnyk funktsionuvannia mekhanizmiv derzhavnoho upravlinnia $\mathrm{v}$ umovakh yevrointehratsii Ukrainy [English language competence as a factor in the functioning of the mechanisms of public administration in the context of Ukraine's Eurointegration ] (Master's thesis), Chernihiv National University of Technology of the Ministry of Education and Science of Ukraine, Chernihiv, Ukraine [in Ukrainian].

5. Druzhchenko, T.P. (2018). Metodyka dyferentsiiovanoho navchannia anhliiskoho usnoho monolohichnoho movlennia maibutnikh yurystiv [Methodology for differentiated teaching English oral monologic production to Law students] (Master's thesis), Taras Shevchenko National University of Kyiv, Ministry of Education and Science of Ukraine, Kyiv, Ukraine [in Ukrainian].

6. Zhovnych, O.V. (2018). Metodyka navchannia profesiino oriientovanoho anhlomovnoho pysemnoho spilkuvannia maibutnikh zhurnalistiv zasobamy bloh-tekhnolohii. [Methodology of Teaching Prospective Journalists Professionally Oriented English Writing by Means of Blog Technologies] (Master's thesis), Ternopil Volodymyr Hnatiuk National Pedagogical University, Ministry of Education and Science of Ukraine Ternopil, Ukraine [in Ukrainian].

7. Zadorozhna, I.P. (2011). Orhanizatsiia samostiinoi roboty maibutnikh uchyteliv anhliiskoi movy z praktychnoi movnoi pidhotovky: monohrafia [Self-Study Work Organisation of Future English Teachers on Practical Language Training]. Ternopil, Ukraine [in Ukrainian].

8. Zaiarna, I.S. (2019). Metodyka dystantsiinoho navchannia anhliiskoho arhumentatyvnoho pysemnoho movlennia maibutnikh pravoznavtsiv [Methodology for distance teaching English argumentative writing to prospective legal professionals] (Master's thesis), Taras Shevchenko National University of Kyiv, Ministry of Education and Science of Ukraine, Kyiv, Ukraine [in Ukrainian].

9. Lazorenko, S.V. (2018). Metodyka samostiinoho ovolodinnia anhlomovnoiu leksyko-hramatychnoiu kompetentnistiu u chytanni maibutnimy viiskovymy fakhivtsiamy z informatsiino-telekomunikatsiinykh tekhnolohii [Methodology of English lexical and grammar competence self-mastering while reading by future military experts in the area of information and telecommunication technologies] (Master's thesis), Kyiv National Linguistic University Ministry of Education ans Science of Ukraine, Kyiv, Ukraine [in Ukrainian].

10. Medvedchuk, A.V. (2019). Formuvannia anhlomovnoi profesiino oriientovanoi kompetentnosti v dialohichnomu movlenni u maibutnikh menedzheriv $z$ administratyvnoi diialnosti [Formation of English professionally oriented competence in spoken interaction of future administrative managers] (Master's thesis), Taras Shevchenko National University of Kyiv, Ministry of Education and Science of Ukraine Kyiv, Ukraine [in Ukrainian].

11. Bakaieva, H.Ie., Borysenko, A.O., Zuienok, I.I., Ivanishcheva, V.O., Klymenko, L.I. \& Khodtsevab A.O. (2005). Prohrama z anhliiskoi movy dlia profesiinoho spilkuvannia [English for Specific Purposes (ESP). National Curriculum for Universities]. Kyiv, Ukraine: Lenvit [in Ukrainian].

12. Government Portal. (2017). Association Agreement between the European Union and Ukraine. Retrieved from https://www.kmu. gov.ua/diyalnist/yevropejska-integraciya/ugoda-pro-asociacyu

13. Harding Keith. English for Specific Purposes. Oxford: Oxford University Press, 2007. 170 p.

14. Pearson Global Learner Survey. (2019). The global Learner Survey. Retrieved from https://www.pearson.com/content/dam/ global-store/global/resources/Pearson_Global_Learner_Survey_2019.pdf

\section{Prokopchuk M. M. Current approaches to prefessional language competence developing}

The article is dedicated to the issue of current trends in teaching English for specific purposes. The last three-year scientific research conducted in the field of teaching English for specific purposes that aims to find out the efficient methodology of the subcompetences as well as the main approaches to teaching English for specific purposes is under consideration. The subject and technological, social and psychological features of learning process and their impact on professional language competence developing are outlined.

The theoretical and methodological premises of professional language competence are highlighted and such approaches as systematic, competent, reflexive, student-oriented in the domain of teaching English for specific purposes in higher education are pointed out. It is claimed that the reflexive approach and the principals of consciousness and the student autonomy development are in favor under the circumstances of global information technology infiltration into all spheres of social life.

In particular, the essence of such concepts as professional language competence, partial student autonomy with inner selfcontrol and outside automatic control, half student autonomy, partially full student autonomy, reflexive approach is revealed.

Having analyzed such standpoints as conceptuality, effectiveness, economy, agronomy, modifying and visualization that were the question of much dispute in the last research dedicated to the usage of information technologies in the English for specific purposes domain, the student additional potentiality tools are revealed.

Such potential ones as 1) flexibility (ability to study during the appropriate for the student time); 2) technology (the usage of the new technological breakthroughs); 3) quality (it is treated on equal terms with traditional education); 4) social equality (the accessibility to higher education services despite the student's residence, health condition and social status); 5) internationalism (ability to get higher education in any institutions abroad) are focused on.

Key words: English for specific purposes, professional language competence, reflexive approach, learning autonomy, information technologies. 